\title{
Chapter 8 Pura's Rashomon Effect (1926-2013)
}

To be free is not a gift, it is a reconquest, and it is necessary to remain silent to build that story that is saved like a long secret that nobody witnessed.

To be free is to nurture a mystery upon which our life is built.

Chantal Maillard, "Spell to tell lies and build truths" (1999) ${ }^{1}$

As I listen now to the tape recording of that hot June 2002 afternoon, from my airconditioned house in Miami, the street noise from the recording triggers a host of memories. I am transported to that hot, sticky afternoon, frustratingly trying to unlock the truth, any truth, from my aunt's tightly guarded memory vault. She does not want to tell me what I want to know. I am hearing her talk, but I am not really listening because I know she is not confiding in me. She knows I know her story, or at least the outlines. I am her family.

She is good at this game, though, presenting her fiction while I pretend to not be aggravated. Because I am family, I don't have the same authority as an outsider. The truth, after all, can be uncomfortable when you have to keep living with someone. I tell myself that this is just one wasted afternoon, me pretending to listen, she pretending to tell the truth, as her yellow canary intermittently chirps on the slowly unfolding tape recording of that afternoon on June $30,2002$.

Ser libre no es un don, es una reconquista,

y es preciso callar para construir

aquella historia que se guarda

como un largo secreto del que nadie es testigo.

Ser libre es tener cuidado de un misterio

sobre el cual se construye nuestra vida.

Chantal Maillard, "Conjuro para decir mentiras y construir verdades," Nómadas: Revista Crítica de Ciencias Sociales y Jurídicas (1999): 135-36. https://webs.ucm.es/info/nomadas/o/chantalmaillard_1.pdf. 


\section{Pura's Narrative}

Figure 23: Pura as a child, 1927

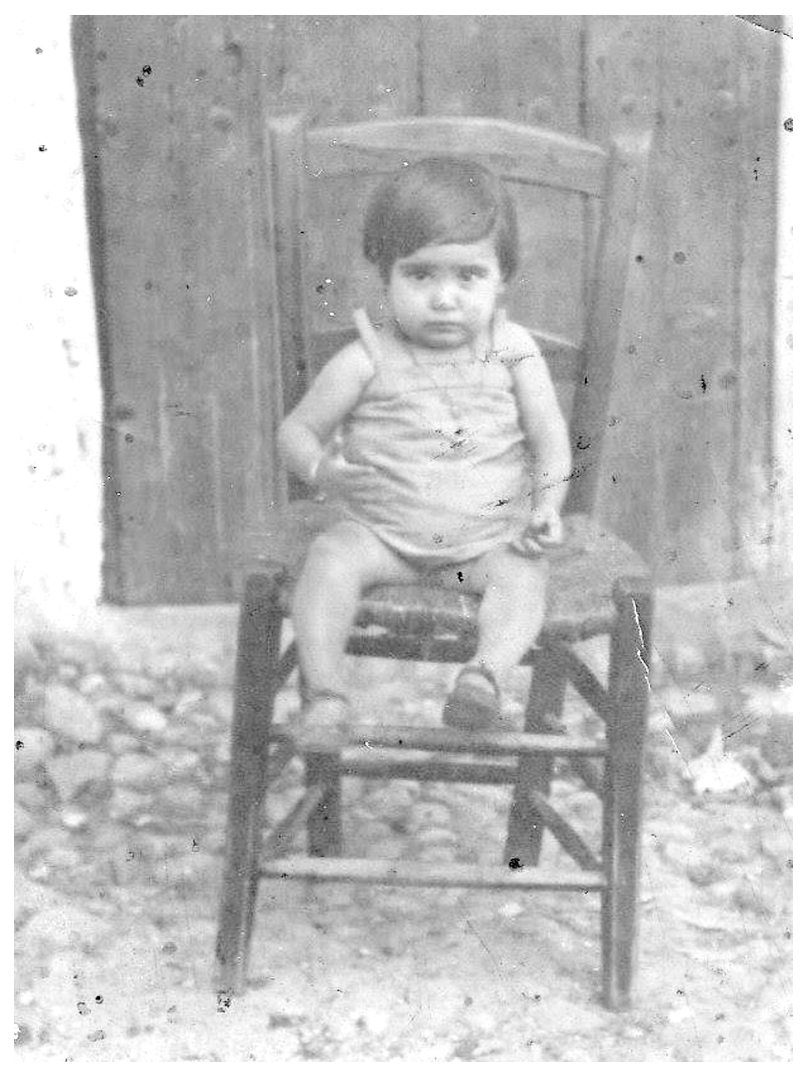

Pura was born on the $5^{\text {th }}$ of September 1926 in Alfacar, a small village only seven kilometers from Granada, and raised in a nearby village called Huetor. When she turned twelve, the family moved to Granada. She remembered going to school in Huetor Santillán: “...Well, it seems to me that I entered school at four or five years of age. I decided to go on my own, not because anybody encouraged or sent me there." With an ironic laugh she remarked, "I was on the wrong path!...had high expectations!... I went to school with a medicine book under my arm." She stares me in the eyes with pride, "...and then, the teacher asked me, 'Did you bring your textbook?' And I replied, 'Yes, here it is."

I can see her satisfaction in retelling that memory as she repeated the teacher's remark as if we were in her presence: "Oh my, we are starting the house in the 
wrong place.... You see, my Uncle Gaspar, my mother's cousin, lived with us and he was in medical school, so I took one of his medicine books to MY school.... I indeed was starting the house from the wrong place!"

Pura is my aunt on my maternal side. Her father, Miguel, and my grandfather, Jose, were brothers. Both had many children and endured tremendous hardships to raise their families as a result of the Spanish Civil War and the immediate misery that followed. ${ }^{2}$ Pura was the oldest of eight: three males and five females. Only ten years old when the war started, she remembered with bitterness having to leave school to go to work and support the family: "I stopped going to school when the war started. We moved to Granada and I, being the oldest, had to help my mother and also work for money. Sewing. In the sewing industry, always sewing. And that way I helped my mother and the household.... She was alone and the two of us had to care for the children...my siblings. My father worked for the telephone company. First, he had worked for the electric company, Conpañía Sevillana, and then he moved to the Telefónica.... I am not sure exactly what he did, only I know he went to work for the telephone company, and he did whatever they asked him to do. Sometimes he would be inside the plant, sometimes on some other site outdoors, but I am not sure because he never talked about his work."

When I ask her to tell me more about her childhood memories of the war, my aunt gets aggravated with my question: "Look, about the war, no...I do not remember anything, and I do not want to remember it. Because I had enough of wars as I have experienced too many. I do not even want to think about it. And as far as my childhood, well, I was very happy. Because I had everything I wanted...although, with the war I had to start helping at home...helping my parents...but my childhood was very happy."

It is clear that her childhood was far from ideal, but it is also clear that Pura is in no mood to talk about it. I try to steer away from this touchy subject and follow with a more personal question pertaining to her coming of age. I ask her about her first period. When I interviewed her in 2002, I was immersed in research for my second book on sexuality and body politics under Francoism. My question was met with similar exasperation. That happened so many years ago I DON'T REMEMBER. I 
DON'T REMEMBER. Determined, undaunted, I ignore her attitude and ask if she was shocked or if knew about it when she had her first menstruation:

"Well, girls always know. In the same way they know about it now. When we were young, we also knew. We knew where babies came from and how things happened. That is common knowledge [irritated tone] always. That was then, now, and a long, long time ago. Since the beginning of times.... Mothers might have seen it as taboo, but girls?... We know much more than our mothers gave us credit. Exactly the same as now."

When I suggest that maybe there was less information available at the time due to Catholic morals, she dismissively replied: "The same, LIFE CONTINUES...those things...I really do not see any difference. Seriously, I do not see it. No, girls always know about our things, and they have always known. Because if you don't know about something, I would tell you and then that passes from mouth to mouth. It was always common knowledge."

"Is that how you found out?" I pressed.

"THE SAME WAY YOU FOUND OUT! And that other one, and that other one. The way everybody finds out about anything. Or about how babies come...when you get married, etc.... We all know those things the minute we are old enough. Because if you do not know something, I will tell you and the next one, and those things pass from mouth to mouth. There are some people I have encountered who pretend to be stupid...and those who pretend to be naïve, but they are not! In the end, they have behaved worse than those others who supposedly were very worldly.... ALWAYS THE SAME THE SAME...YESTERDAY, TOMORROW AND FOREVER...."

I have upset her now.

"That's how some pretend...pretending they are naive until it is obvious that instead they are too smart for their own good. Those things...Aurora...I do not appreciate it."

I move to what I think are safer waters, asking her about her leisure activities as a young woman. Did she go to the movies or read novels? She replied, "ME?!... No, reading novels has not been my choice. I only liked to read serious educational books. Novels and comics were not to my taste. I used to read books that sometimes fell into my hands, sometimes not. Instead of reading a novel I would rather sew or embroider or do something else. But not for me...most certainly not novels...I did not even like to listen to them."

Pura was most likely referring to the "radio novelas" popular at the time among homemakers. She continued, "Nowadays, perhaps I find some entertainment in listening to them because I cannot sew very much as I have bad eyesight. But really for me, whenever I find a good history book or something like it.... A good book always rather than a novel...not interested.... You see, for me, let me tell you...since I was a little girl I wanted to learn and could not.... Well, I did not want to waste any time reading something I would not like.... I would have studied medicine if 
I could. That was my dream and even now...look, I have collected medical books, about medicinal plants, and I have devoured them but not a novel. If I have an ailment, I know how to take care of myself, better perhaps than other people who are not familiar with home remedies...this herb or that other is good for that or the other.... When I visited a doctor, rather than using the medication he prescribed I would use herbal treatments of my choice. [...] Because I have studied all those things.... It is what I am trying to tell you.... When a person likes something.... Let's see, why do you know about history? Because you like it, right? And seek information, right? Now you are researching, seeking information, learning from me.... Well, in my case, I like medical stuff...everything on the subject I have been able to learn, I have read, studied...I brought some medical books from France ...but some boxes with my books were lost in the move...."

Her mentioning France gives me a chance to ask her about her experience abroad. I know she got married to Juan, a Spanish man who came all the way from Algeria to marry her. I would like for her to tell me about how they met that day in August 1958 when he came from Oran across the Mediterranean. Pura's response, unsurprisingly, is not very revealing: "It is of no consequence, how I met him...because it was my destiny. He had to come to meet me. You know, that man did not live here, he lived in Algeria...and he came to visit Uncle Jeanot who was his friend ${ }^{3}$.... He came, we got to know each other, and he fell in love with me...and I liked him. So, we arranged everything and got married here [in Granada] in the Iglesia del Salvador, of course, where else? Perhaps I could have gotten married in another church but since we had to do it quickly before his return and had very few days in between.... Because as soon as he met me in person...we met on August 2, got married on the 28, and he returned to Algeria on August 30."

"You did not know that, right?" She looked intently into my eyes with a halfamused smile. "We got to know each other before through correspondence and photographs...I saw him first in that picture over there." She pointed to a picture of her husband displayed prominently on the other side of the room. "He sent me a portrait so I could see him. When he came in person, I liked him, his presence, his manners....and so we got married...I was almost thirty-one.... Then, I had my Mari and my Carmen [their two daughters]."

3 Jeanot had married Mercedes, one of Pura's younger sisters, and was in Cranada. Jeanot, also Spanish, and Juan had been neighbors and friends in Oran for years. 
Figure 24: Pura (on the right) on a stroll with her sister Mercedes and her husband, a close friend of Juan's who showed him this picture, which led him to pursue Pura

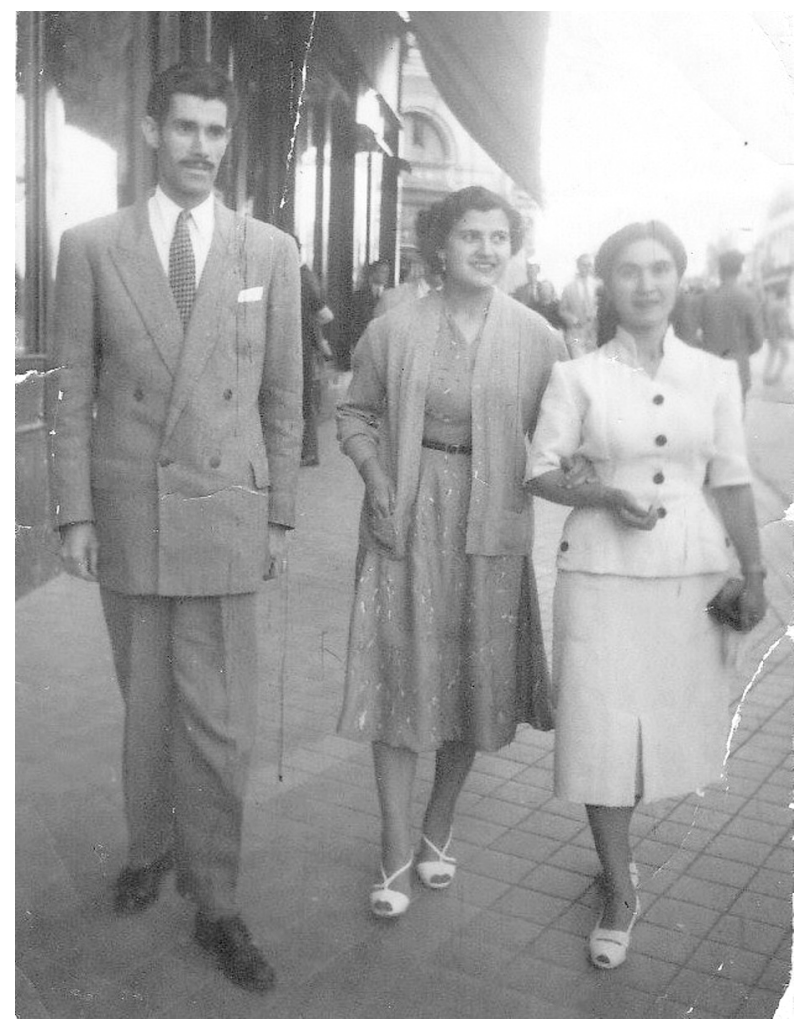

I asked Pura about her first impression of Algeria, when she arrived in Oran. That was her first time outside of Granada. "When I arrived there, I thought it was paradise. Because I was used to...you know, Granada in those days, Granada was a very beautiful city. It shined with its cleanliness and so on.... Granada may have been a small town but it shined like a silver cup. It was clean as fresh spring water. When we came early in the morning to work, down the Calderería hill from the Albayzin to downtown...the street sweepers were finishing scrubbing, street by street. Now our streets are dirty...now Granada is grimy, but then, it was like a precious little silver cup, everything gleaming clean. No one could shake out even a tablecloth out their window because you got a fine. Today we only see filth. So, I was used to Granada and when I arrived in Oran, well...upon arrival I was not very impressed. It was in the evening that your uncle took me out for a stroll...because we 
lived, let me think how best to explain it to you.... Like our Gran Via, there was the main avenue in the city center and we lived in what we call here in Granada Elvira Street, parallel to our Gran Via, just like it. So, when we went out at night for a walk down the main avenue...I was enchanted, really enchanted. For me it was...a Little America...that is what Oran was for me...an America in miniature. Because...how can I describe it to you?... I saw everything with impressionable eyes.... If you go to a place you never saw before and you see it in all its grandeur.... Well, let's see.... What did you feel when you arrived in America? After your departure from a beautiful town like Granada...."

Figure 25: Their wedding in Granada, August 28, 1958

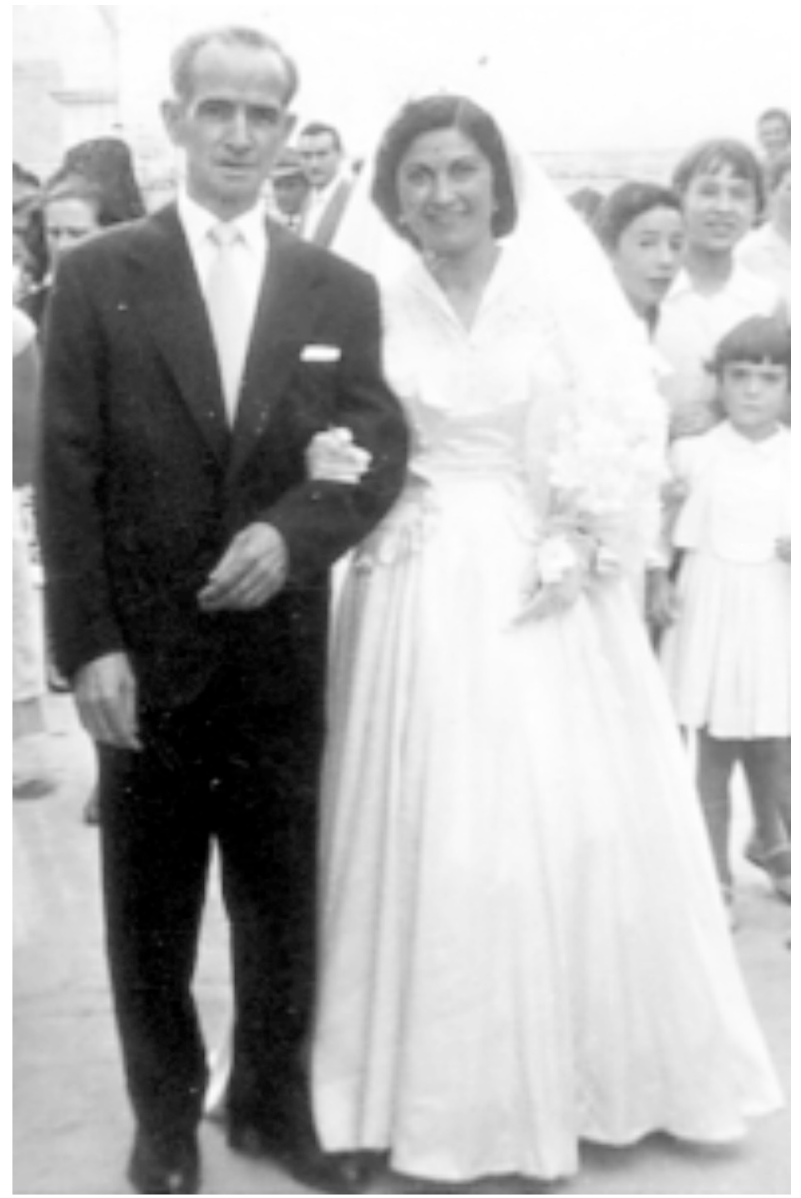


Obviously, my aunt had never visited America. What I believe she is trying to tell me is how foreign her new home felt. She tries to connect her experience with my own when she compares it to my move to the United States in 1989 to pursue a Ph.D. at the University of New Mexico in Albuquerque. I tell her my experience was amazing as well, not wanting to explore with her my own difficult truth. As an interviewer you are not supposed to interject your own story, but in a way you do. When I listen to my words on the tape, I reflect on the true experience of displacement in a foreign land in order to imagine what my aunt might have experienced being alone in a foreign country, away from her hometown of Granada, for the first time in her life.

My mind drifts uncontrollably to August 9, 1989, when, after twenty-four hours of flying (Málaga to Madrid, Madrid to Dallas, and Dallas to Albuquerque), I finally arrive, exhausted, in Albuquerque, New Mexico. The airport feels small, more like a bus station. No one is there to greet me, so I take a taxi to the motel that had been recommended by the parents of an exchange student from the University of New Mexico that I had briefly met in Granada a couple of months earlier. The driver drops me off at the front office of a motel on the main street to the university, Central Avenue. A disproportionately large flickering neon sign of a smiling cowboy beckons weary travelers to the "Highway House." It hits me that I am truly in America and not the America of glamorous Hollywood movies. This feels more real, real in the sense that the working-class neighborhoods of my childhood feel more real than the fairytale palace of the Alhambra. The rooms all face inward, giving the guests unobstructed views of the dusty sedans and trucks slotted into the rectangular courtyard. A large woman at the motel's registration desk asks me to pay in advance and in cash for my three days' reservation. Who am I to question the customs of my new country? As I pull out my wallet to pay, I notice a couple of older men lounging on the red vinyl couch in the tiny lobby. One of them, smelling of beer and cigarettes (something strangely familiar to a Spaniard of my generation) and dressed in jeans and a stained t-shirt, wordlessly slouches over to take my blue hard-case Delsey. I am momentarily confused. In Spain, hotel employees are readily identifiable by their uniforms and high standard of grooming. Shoes are shined like mirrors and shirts starched and pressed. I make a mental note of this cultural difference. I stifle a laugh as I watch the overweight man strain to lift the manuscript-laden suitcase before leading me down a concrete path to my temporary home.

It occurs to me that I have not thought this adventure through well enough. When I call my parents, I assure them that everything is fine. The local news telecast offers an update on all the murders in town. After double-checking the lock on my door, I call the local family who I had met briefly in Granada months earlier and ask for the number of the police department. In fifteen minutes, they are at my doorstep, whisking me away to their house and leaving behind the prostitutes, 
drug dealers, and drunks that inhabit this stretch of neon-lit motels along Central Avenue.

My point is, what my aunt was telling me was a fairytale. What I knew to be true was that Pura was fed up with her life before she turned fifteen but could not get out of Granada until she was thirty-one. Her ticket out was her marriage to a stranger with a French accent, owner of a prosperous pâtisserie, La Colombe, in Oran. She flew across the narrow Mediterranean waters and became Madame Casquero in the summer of 1958. Seven years later, war and violence forced them to start all over again in Toulon, France, as one of many relocated pied-noir families.

Pura tells me her husband was a Spaniard who had migrated to Algeria when he was sixteen years old. He held on to his Spanish but also learned to speak French and Arabic. According to Pura, learning French was not an issue for her as she picked up the language by watching TV and through her daily interactions with others. She tells me Juan was the love of her life, and even after his death, that she has not been able to find anyone to replace the void his departure left in her heart: "He...He was the love of my life. Very special to me because he gave me everything in exchange for nothing."

Figure 26: Pura and Juan, Souvenirs D’Oran
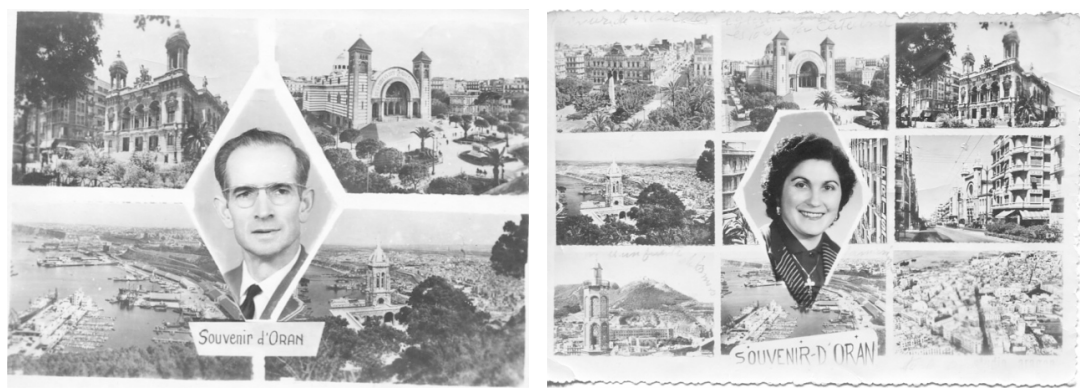

When I ask her if her parents had any objections to her marrying and moving away, she replied with a defiant tone: "WHAT OBJECTION COULD THEY POSSIBLY HAVE? I WAS ALREADY THIRTY YEARS OLD. Of course, my mother suffered because of my decision because I was truly everything for her, as if she were losing her feet and her hands. But that was my decision, and nobody was going to deter me. I met him in person at night and I did not...really feel a spark.... And thought, 'he will go back and that's that. In the very same plane that has brought him here, he will leave tomorrow.' But the following day, when I saw him again, I changed my mind. I liked him better. I liked his presence, his kind manners, his demeanor. He was very elegant, and I liked him very much. And I thought to myself, 'Oh no, you are not getting away from me.'...It was fate; he was meant for me." 
"We had to wait three months to be reunited after the wedding.... I took the train from Granada to Alicante and from there, I flew to Algeria. That was my first time flying. My Mercedes and Jeanot went on vacation to Algeria with their little son Juanmi, so they accompanied me to be with my new husband. You see, I could not go with him after the wedding but rather had to wait for him to claim me as his new wife. I got my passport to cross the sea and leave Spain...to go to a strange country where they spoke French.... France had to give me a visa and someone had to claim me as his wife, you understand...and that is how I was able to leave because in those days you could not leave Spain just because you wanted to. Once I arrived, I applied for my national card and went to the Spanish consulate to register as a legal. It took three months between our wedding in August and my arrival in Oran when we reunited."

I interject casually, "Uncle Juan was a widower, right?" "NO!" she replied emphatically, "he was not a widower or was never married ever before. I was his first and only wife."

Figure 27: Pura's arrival in Oran with Mercedes, Jeanot, and their son in 1958

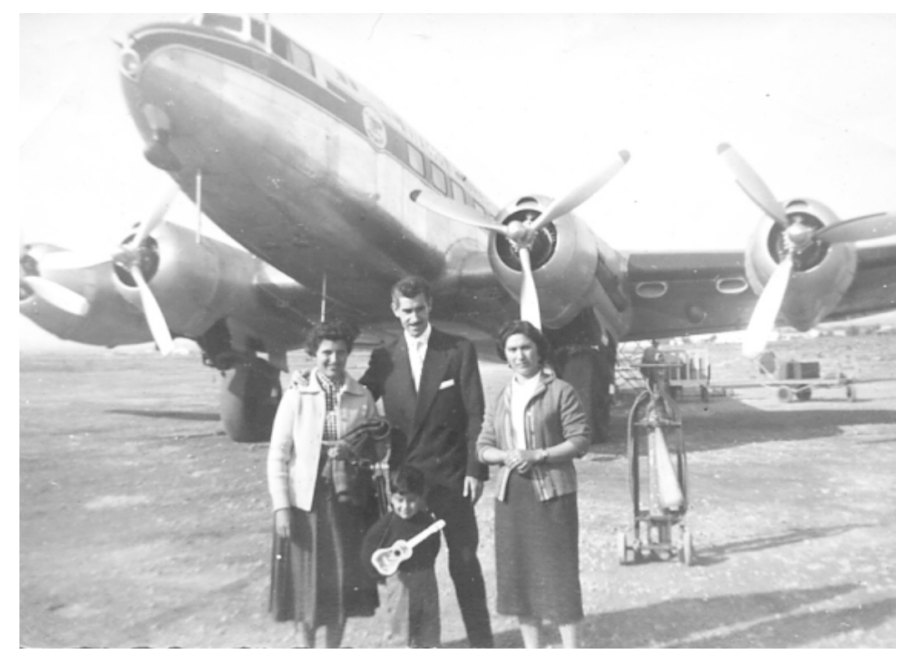

Her answer surprises me. All the family knows Juan Casquero was a widower. I don't press her, knowing that that would be a dead end.

I switch to the topic of work. Pura explained, "I never worked abroad, I only worked when I lived in Granada. Clearly, I was very aware of what I could do. All my life...I have been...I have considered myself not just a girl but a woman. Young but very mature. First of all, because as the oldest of eight siblings, I had 
a lot of responsibility and knew how to handle it. I was only fourteen years old when I first went to work in a factory, and I remember I was not welcomed by any of the women who were there. I MADE FUN OF THEM!! OF THEM!! [with emphasis] being just a kid, fourteen years old. My mother had no need for us to work as domestics, and Aunt Paca, my father's sister, told me, 'Oh [Pura changes her voice to a contemptuous tone] my child, you should do what Prima Josefa has done.' '...What has Prima Josefa done?' 'Well, she serves in a house.' [Pura changes to a contemptuous voice again] 'And they dress her and feed her...and the salary she earns is for her to buy her trousseau.' And you know what I told Aunt Paca, may she rest in peace [changes to a resentful and grave tone], 'Why don't you put your own daughter to serve?' I asked her. 'Why don't you put your daughter to serve, Aunty?' [again, Pura changes to a contemptuous tone in her intonation as if Auntie Paca were in the room with us]. 'Because my daughter is not like you!"

Then Pura uttered an angry, triumphant reply, looking intently into my eyes. “NO?! OH, MY COUSIN IS NOT LIKE ME? Well, it so happens that you are my father's sister, and I'll SERVE NOBODY !!' Because I have two hands to work.... Today I'm in the factory working, in a factory... maybe tomorrow I'm at home working in another way. But to serve...I would rather work in the factory and start sewing, embroidering, and just working in my own house, without needing to go anywhere. Because I WAS A LADY and I did not have to go to another girl like me and call her 'Miss'...NO, NO, NO."

"Because in our house we were poor; in our poverty, we have lived it behind closed doors...but not in public! What has happened in my house has never been known out on the street. So, we did not give the impression of being poor. Do you understand me?... Because nobody knew about me...if at home we missed eating one day...we did not go around saying we did not have anything to eat. In my house that never happened...EVER! We worked. Everything I earned I gave it to my mother so we could get ahead. But nobody ever knew what was missing in my house.... Because we showed ourselves well to the world...well dressed, well groomed...because we made our own clothes, because my mother sewed for us and made her own clothes and when we were older, we did it ourselves. We have never given the impression that we were poor."

"Living abroad I have done nothing outside the home. Although I wanted to, Juan never let me go out and work because he felt he made a good living with the bakery. And so, I had my children in a private clinic with a private midwife. I never had to step in a hospital. Everything was private and paid for."

They lived in Oran for seven years until the Algerian war forced them to leave their prosperous business and happy life behind. Pura recalled, "We had to leave 
because we could not live among the Moors. We are not Moors...we are Europeans. ${ }^{4}$ I returned to Europe and left Africa. We moved to France. Toulon, because it was similar in climate to Oran, close to the seaside. And we stayed in Toulon another seven years and after that we came to Granada. We were from Granada and once we got our retirement, where else would we go? If it had been up to me, we would have stayed in France. I liked it there much more than here. But Juan wanted to return to his Spain, and I could not say no. I liked everything about the foreign countries we lived in. Everything, everything, everything...I liked everything. I lived very well, very comfortable, very respected by everyone. Everybody appreciated me...even strangers treated me with kindness. At the beginning it is hard but once you acclimate yourself...it is the best. Surely, there is good and bad everywhere, but you have more freedom. The world and its people are all the same everywhere."

When I ask her about the escape from Oran, she said bitterly, "We closed down our business and left everything behind. They stole everything from us. I did not say I was leaving for good but rather that I had bought a flat abroad and was sending some of my furniture to that new apartment and on our return I would buy new furniture for our place in Oran.... We could not sell the business...the bakery. We had to turn the key, close the door, and flee. Leaving everything there. House, business, a lot of land we had bought to build a little summer house...EVERYTHING. We left to start from scratch. Zero. Juan wanted to open a new business [in Toulon] but I did not want him to. I told him we would only open another business when we were living in our own country.... But while we were living in a foreign land, he better work as an employee and earn a salary. No more businesses...as any day another crisis could explode and they all tell you again that you don't belong in this land...whatever we were to invest in it must be in our homeland so nobody could claim ownership. Only when we returned to Granada did we open a little bakery. So, in Toulon he started working at a bakery as an employee and did not want me to work but I did want to. There was an opportunity to work in a sewing workshop for me, but he did not let me." plained by Eric Calderwood: "In modern usage, the term can refer to many distinct categories, including Muslims (a religious category), Arabs or Berbers (ethnic categories), inhabitants of al-Andalus (a historical designation), and the people of North Africa or Morocco (regional or national categories). Like the term "Oriental," the word "Moor" tells us more about the person who uses it than it does about the thing it supposedly describes. It is thus best understood as a category of the Spanish imagination rather than a descriptor of peoples or cultures." Eric Calderwood, Colonial al-Andalus: Spain and the Making of the Modern Moroccan Culture (Cambridge: Harvard University Press, 2018), loc 613 of 9328, Kindle. 


\section{Rashomon Effect}

When trying to understand my aunt's story so many years later and after she had passed away, I realized that there were lots of missing pages, pages that she deliberately tore out and threw away. I decided to find others who might be able to ghost write her past with me. I reached out to her two daughters and also to her younger sister, Pili, who lived with the family for almost two years in Oran. Over the course of various conversations held on the telephone and in person over the course of a year, the four of us reconstructed some of the highlights of my aunt's life. My pursuit is best described by what is called the "Rashomon Effect," based on Japanese director Akira Kurosawa's film Rashomon (1950). ${ }^{5}$ Kurosawa utilized an unconventional non-linear narrative in his adaptation of the story "In a Grove," by writer Ryunosuke Akutagawa (1892-1927). Set in eleventh-century Japan, "In a Grove" tells of a heinous crime: the rape of a noblewoman and murder of her Samurai husband, supposedly by a bandit in their journey through a forest. Kurosawa utilized flashbacks to re-tell the incidents through four witnesses' testimonies (the woman, the woodcutter, the bandit, and the Samurai's ghost). The film provides a valuable artistic reflection on the relativity of truth and the unreliability of memory. These two accusations have been the main criticism at the core of oral testimonies as accurate primary sources in History's noble pursuit of “objectivity." I use this technique not to uncover some objective truth of the events of Pura's life, but rather to understand the process of constructed memory in historical retelling.

The most important moment in Pura's life was no doubt her marriage to Juan Casquero in 1958. Her move to Algeria and then France in the next long decade had a profound effect on her family's life. Twice she had to start a new life from scratch in a foreign land. Yet, she whitewashed much of the hardship from her life's narrative. Her power resided in her conscious forgetting, rewriting, and refashioning of herself as an adventurer rather than a victim. In her telling she is almost heroic. Listening to the testimonies of her two daughters and her younger sister who lived with them in Oran the last year of the revolution gives us another perspective.

\section{Pura's life according to her daughters Carmen and Marian}

According to my cousins, Juan Casquero was born in Almería in 1906 and lost his mother at the age of twelve. When his father remarried, he and his two brothers were sent away to Oran, Algeria, to live with his aunt, who worked as a doorkeeper

5 On the "Rashomon Effect," see Rashomon, directed by Akira Kurosawa (1950; Tokyo: Daiei) ht tps://www.criterion.com/films/307-rashomon. 
for the city's historic newspaper, L'Écho d'Oran ${ }^{6}$ He did not attend school in Oran but rather started working as an apprentice in a pastry shop where he learned the trade that would eventually make him a successful businessman. When he arrived in western Algeria, he was not in strange territory. The Andalouses beach and Oran region had been under Spanish control on and off since 1509. After the earthquake of 1792, the Spanish crown turned Oran into the Algiers Regency, and in 1830 the French became the colonial power in the region. ${ }^{7}$ Nonetheless, the Spanish presence in the Oran region grew during the nineteenth century. The agrarian crises caused by droughts and floods in the Spanish southeast during the second third of the nineteenth century were the primary causes of the Spanish emigration to the Oraine district. The geographical proximity of Oran with the Spanish ports of Alicante and Cartagena and the climatic similarities between the Algerian territory and the Spanish Levante drew many day laborers from Alicante and Almería to embark on an uncertain and risky move. Initially this emigration was temporary, but by dint of repeating the cycle, many ended up staying to work in the cotton or tobacco plantations as well as in the vineyards. Others came to build the railroad between Algiers and Oran. In 1840, Spaniards represented almost half of the Europeans in the cities in the Algerian territory and were almost the only ones in the rural areas. The French Constitution of 1848 divided Algeria into three regions: Algiers, Oran, and Constantine. Of the 257,000 European inhabitants in the 1850 Oran census, $65 \%$ were of Spanish origin. ${ }^{8}$

In 1882 more than twenty thousand Spaniards arrived at the port of Oran, half of them from Almería. Three years later the Spanish colony in Oran had 80,000 individuals permanently established in the region, 30,000 of them residing in the capital. In the districts of Oran and Sidi-Bel-Abbés, the Spanish population was double in number to that of the French.

To address this problem the French issued a series of laws headed by the decree of June 28,1889 , and later by another of July 23,1893 , which imposed, without exception, French citizenship on all foreigners born in Algeria. The law of automatic naturalization was like a magic trick that turned Spaniards into French

6 L'Écho d'Oran : journal d'annonces légales, judiciaires, administratives et commerciales de la province d'Oran (184?-1963); see Bibliothèque Nationale de France, Département Droit, économie, politique, JO-13582 http ://catalogue.bnf.fr/ark:/12148/cb32759772v.

7 On the Spanish presence in North Africa see: Sasha Pack, The Deepest Border: The Strait of Gibraltar and the Making of the Modern Hispano-African Borderland (Redwood City, CA: Stanford University Press, 2019); Calderwood, Colonial al-Andalus; Juan Ramón Roca, Españoles en Argelia: Memoria de una emigración (Alicante: IES Luis García Berlanga, 2016); Susan MartinMarquez, Disorientations: Spanish Colonialism in Africa and the Performance of Identity (New Haven, CT: Yale University Press, 2008). For a history of Algeria see James McDougall, A History of Algeria (Cambridge: Cambridge University Press, 2017). 
overnight. This bureaucratic solution to the Spanish overpopulation did not immediately change the reality of the immigrants but, combined with French-only schooling for their children, subsequent generations became more French than Spanish. ${ }^{9}$ The Oraine district's Spanish population decreased from 102,433 in 1891 to 78,000 in 1930 . The French population grew in the same period from 98,724 to $273,000 .^{10}$ However, the presence of Spaniards in the region continued to grow. When Juan arrived in 1919, new trades started to grow alongside the agricultural jobs. After the First World War, the ice cream and pastry confectioners, canvas shoe and leather apparel artisans, anise distillers, and potters from different provinces in Alicante established their businesses in Oran. Many set up their factories in Algeria to avoid tariffs. ${ }^{11}$ Women were employed as workers in factories and shops, as domestics, shopkeepers, and concierges. Juan lived with his aunt, who worked as a concierge. By 1931, according to historian Juan Ramón Roca, 65\% of the foreign population came from Spain. The Spanish Civil War added the Republican exiles to the labor migration with around 15,000 newcomers who fled repression from Franco's regime.

The best-known incident of Republicans fleeing Spain concerns a coal ship, The Stanbrook, ${ }^{12}$ which sailed on March 29, 1939, with more than 2,600 passengers. Upon arrival in Oran they had to wait six days before women, children, and the sick were allowed to disembark. After twenty days on board, a typhus epidemic broke out, and the ship was quarantined. The French decided that they could no longer accept the growing number of refugees flooding their North African shores. Thirteen thousand were imprisoned in seven concentration camps south of Algiers, some located in the middle of the desert. Many had to wait until the American liberation during the Second World War to be freed.

In 1954, after France's refusal to develop a decolonization plan for Algeria, a liberation war broke out that culminated in the country's independence in 1962. It was at the beginning of this revolutionary war that Pura's marriage began.

Pura got pregnant soon after she arrived in Oran. This event might not have been such a happy occasion for a number of reasons, as I learned in my conversa-

9 Roca, Españoles en Argelia, 60.

10 Roca, Españoles en Argelia, 71.

11 Roca, Españoles en Argelia, 77-78.

12 For a detailed account of the Stanbrook event see Juan Bautista Vilar, "Guerra civil, éxodo y exilio: La aventura del Stanbrook, Alicante-Oran, marzo 1939," Estudios Románicos 2 (Universidad de Murcia, 2007-2008): 213-27. Available at: http://revistas.um.es/estudiosromanicos/ar ticle/view/94691/91111. Juan Bautista Vilar is the authority on Spanish emigration to Algeria; see: Juan Bautista Vilar, La emigración española a Argelia (Madrid: C.S.I.C., 1975); Los españoles en la Argelia francesa (Madrid: Centro de Estudios Históricos, C.S.I.C., 1989, 1989); La emigración española al Norte de África, 1830-1999 (Madrid: Arco-Libros, 1999); El exilio en la España contemporánea: Las emigraciones políticas españolas en los siglos XIX y XX (Madrid: Ed. Síntesis). 
tions with Carmen, who was born in 1959, and Marian, her younger sister. Their recollections may explain why Pura told me she was Juan's only love and wife. Maybe she happened to be his only true love but, certainly, she was not his only wife. Marian explains why: ${ }^{13}$

Figure 28: Family portrait, 1963. Pura holding Marian, with Juan standing behind Carmen

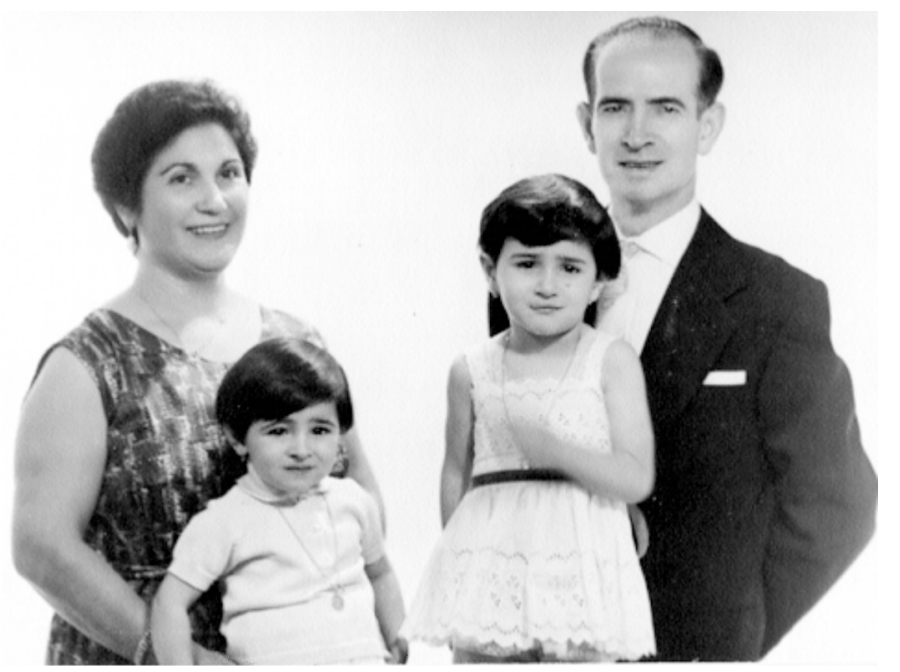

"Of course, that was a secret. It was a thing that...look, we found out because we were very curious girls, my sister and me. And we liked to enter into my parents' bedroom to go through their drawers, to see what we could discover. And we found the Family-Book, ${ }^{14}$ and so, one day reading it, we must have found it on a table or something because they were using it for something...we noticed it said HE was a widower! And my sister and I secretly read it. '...Oh look there it says that Papá was a widower!' But nothing happened, we let it be a secret. Later, Auntie Pepi, I remember, she did tell us something more about it...how they met and so on.... Although it was nothing bad to hide.... Well, no, no! Well, I do not know. She [Pura] did NOT like to talk about it. Also, my mother was badly regarded by his first wife's family. When she arrived in Oran, the first wife's family still lived there. That woman had not been able to have children, and they blamed it on my father. He had a number of nephews and nieces, all aware of and expecting my

13 Marian CasqueroGómez, phone interview recording, June 2, 2018.

14 Married couples registered each new birth in the Family Book, the official Spanish government registry. The Francoist regime rewarded prolific families, starting at four children. 
father's inheritance. When they saw my father show up with a younger woman and that she became pregnant...then their inheritance...went poof!! and disappeared. Ah see? ...when my mother got pregnant the gossip ensued: 'Who knows who the father might be?' etc.... You know? Surely, that's why she did not talk at all about that, and that family disappeared from my father's life the hard way...because they distanced themselves from my father, but that's why. Because the family wanted the inheritance. 'If he does not have any heirs then everything is ours,' they thought...."

Pura was not interested in motherhood, according to Marian. If it had been left up to her, she would have been happy with only one child. "So I believe that my mother," Marian speculated, "after having raised 8 or 10 , or 12 or whatever number of siblings, she might have thought, 'Me again taking care of children?'...and knowing my mother's character...as she was a woman with a strong personality...with a lot of determination...a woman who always fought and overcame everything, and endured many troubles and hardships...because they had not gone hungry since my grandfather worked for the telephone company and food was never lacking, but clothes, shoes, and other things were scarce for so many children. And then my mother grew restless, she wanted to learn and could not, wanted to go to school and could not. She worked very hard, driven by her eagerness to learn, learn, and learn.... But she was my grandmother's hands and feet and...the family stifled her thirst for freedom...they clipped her wings. And of course, when she saw an easy way out, she must have said, 'Well, I'll get married and get out of here and start again...or I can live differently, be happy, have time for me.' ...And so, then my sister came; they did not expect that pregnancy but the gossip...well, it so happens that my sister was the spitting image of my dad.... My dad was older, and she didn't like the idea of having more children very much.... But my father insisted, and I came to exist because of him, otherwise...[she laughs]. He was more paternal and he said that a girl alone was not right...since he had had that yearning...that is why I was my daddy's girl and my sister was my mom's...I simply adored my father. ...I remember that my father had a red leather armchair and the two of us fit in it [giggle]. It was my perfect place...for me. And if we went for a walk, I was always with...my father. And my sister, as she was also born with health problems, and maybe my mother was more concerned about her. I do not know; but they always have been very fond of each other...very close."

Marian and Carmen's first years of schooling were in French, which meant a hard adjustment for them when the family relocated to Spain from Toulon in 1971 after their father retired. It was the French school that played a decisive role in the social cohesion of the European collective in the colony. The only public school run by the Spanish state was in Algiers, and it had closed its doors in 1870 due to lack of resources. The Spaniards sent their children to French schools that had better resources and offered advantages. Carmen went briefly to a school run by nuns. Many Spaniards became bilingual or even trilingual (Spanish, French, and Arabic), 
as was the case with Juan. From all this mixture of languages was born the so-called "patuet" dialect, a mixture of the three that in the Oran region received the name of "chapourlao," from the Spanish "chapurrear"(jabber, to speak a broken language).

On October 1, 1954, the war of independence in Algeria began with a series of terrorist attacks claimed by the FLN (Front of National Liberation). The conflict lasted seven years, eight months, and three days, finally forcing the pied-noirs, the Europeans in Algeria, to choose between fleeing the country or resisting within the clandestine OAS (Organisation de l'Armée Secrète or Secret Army Organization). ${ }^{15}$ In France the pied-noirs were often seen as primitive and uneducated people. ${ }^{16}$ of the entire foreign colony (Spaniards, Italians, Maltese, Swiss, and Germans), the Spaniards represented the group with the lowest cultural capital because they came from the most impoverished ranks of society. At that time in Spain, only $31 \%$ of men and $9 \%$ of women knew how to read and write. In addition, the emigrants came mostly from the southeast of Spain, one of the poorest regions in the country with the highest illiteracy rates. In Algeria, relations between the French and Spaniards were not always cordial. The Algerian administration and the French press in general were suspicious of them. The Spaniards lived grouped and isolated from the French community. Throughout the twentieth century, a strong feeling of belonging to the country was formed by the pied-noirs, regardless of their origin; they felt they were Algerians. Some came to dream of a "Free Algeria" of France. OAS, the pied-noirs' clandestine resistance group, came to confront the French army and the French colonial establishment. When the conflict broke out, many Spaniards living in Algeria actively participated in the OAS.

When Juan Casquero originally married a French woman, he renounced his Spanish citizenship. He built a successful business in Oran and felt at home in that city. But with the revolution he lost everything and had to leave with his family to save their lives. According to his daughter Marian, "He lost everything. He lost it

Roca, Españoles en Argelia, 104-06. The OAS was founded in Francoist Spain shortly after Ceneral de Gaulle started negotiations with the FLN for independence. Some French military officers met in Madrid after the 8 January 1961 referendum on self-determination and established the OAS, a right-wing dissident paramilitary organization that carried out a violent counter-terrorist campaign in the next year until Algeria's independence was proclaimed on 5 July 1962.

16 Pied-noir was a term first used by Algerian indigenous peoples to refer to the military and first French colonists, referring to their black shoes and boots they wore. A term originally applied pejoratively, during the war of Algeria, it was embraced with pride. On a contemporary assessment about the pied-noir community in Algeria in 1962, see Alfred Sherman, "Climax in Algeria: The O.A.S. and the Pieds Noirs," The World Today, 18, no. 4 (Apr., 1962): 134-42. Available at: https://www.jstor.org/stable/40394178. The Algerian War remains an emotional issue in contemporary French Politics. In 2014, the ultra-right leader of the Front National (FN) Marine Le Pen addressed a letter to "the Harkis and pied-noirs" in which she declared De Gaulle had abandoned them. 
because he was not intelligent in that regard. But my father, with his caring quiet character, everyone loved him. Because he had an affable personality, he was calm, he was a man who didn't care if they were Moors or not...he made no distinction and was a man who got along well with people. So, they told him, 'Mr. Casquero, leave. Take your girls and your wife and leave or you will lose everything. They won't give you anything.' But my father was stubborn. Because, of course, with so many years living there, he asked how they were going to take away what was his and what he had worked so hard for. It did not enter his mind that he was going to lose everything. And he did not understand that things were getting worse.... Well, I remember...Aunt Pepi who came from Granada when I was born, was there with us...bombs were falling.... And the revolutionaries attacked.... They put a bomb over here, a bomb over there. And Aunt Pepi would take us into a closet every time she would hear a plane or anything...or every time sirens sounded.... And she hid us in the closet.... Once, later on, my sister and I...we were traumatized by that.... Because growing up every time I heard a plane I became paralyzed and I had to wait for the plane to pass...one day I told my sister. I said, 'Carmen, is this happening to you?' And she tells me, 'Yes,' and we asked Tita Pepi, as she liked to tell us things about the time she was in Oran... and one day...she had repeated it many times, but we had never realized.... And that time she told us again, 'And we were in the closet and you were crying a lot.' And these are lingering images I have of when there was so much trouble...." The fear my cousins expressed was never revealed in my conversation with my aunt. She never mentioned the hardships they all endured in the seven years of the war.

Fear is still vivid in my Aunt Pepi's recollection of the two years she spent in Oran with her older sister. Pepi was almost twenty years younger than Pura. When Marian was born, she went with her father to meet her nieces. Pura asked their father to let Pepi stay at least for a year so she could learn French and help with the babies. That was the summer of 1961. Pepi was thirteen years old and remembers how well established and comfortable she found her sister. Pura from Granada had become the prosperous Madame Casquero. "So, the truth is," Pepi remarked, "that I did not suffer any scarcities.... We had plenty of food...I only remember the FEAR!" According to Pepi, her sister Pura made a great choice marrying Juan and escaping the gossip in the little neighborhood in the Albaycin. Pura borrowed the wedding dress of a neighbor and got married within a month of Juan setting foot in Granada and three months later left for Oran. "I remember," she told me, "we read her letters aloud, 'Mama, I'm very well, this is a paradise for me'... Well, indeed, it was a paradise, because Juan was doing very well economically. The bakery they had was called 'La Colombe'... 'The Dove. ${ }^{17}$ 
Figure 29: Wedding cake by Juan La Colombe pastry shop

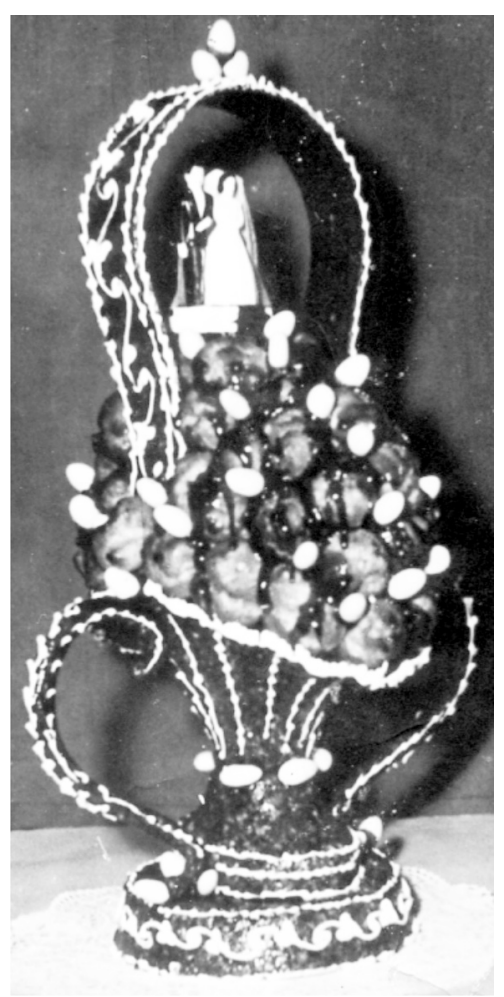

Pepi also liked Oran. Pura and Juan decided enrolling her in a school to learn French might not be a good idea since the tensions started to heat up shortly after her arrival. Instead, Pepi started taking classes with a neighborhood French girl a few years older than her. To practice speaking French, Pepi would spend time in the pastry shop talking to the attendants Juan employed. There were also two men who worked with Juan, one of them a young Arab who fell for Pepi: "Then at that time things started to become violent.... And she [Pura] realized then, 'I cannot send you back, neither can we leave.' Juan, [Pepi gets agitated and starts crying] for me, he was like a father [choking with silent tears]. He would say, 'You don't have to be here.' And to my sister, 'Pura, send her back.' [Crying] And my Pura would say, 'I can't. How do I send her? How do I send her?' Then, at the pastry shop there was...a young Moor. And the Moor, well look...he fell in love with me. And Juan told me, 'Don't come downstairs.' 'But, Juan I only.... 'DON'T COME DOWNSTAIRS! Don't 
go down, I'm going to get into trouble!' Of course, they could not send me back. Well, I was there and of course I couldn't leave. Then there were the two baby girls. Pura had to go out to shop... and then.... They started putting bombs in different places and businesses. Juan was never a target, never bombed because he was loved by both the Christians and Moors as well as the Algerians and whoever else owed him favors. The young Moors who worked for him would repeatedly tell him to leave: 'Señor Casquero, leave! Otherwise you're going to leave with nothing! Then they will kill you.' 'No, no ...,' he would say, 'How could they kill me? I have grown up here, since I was twelve, and I am one of them? I haven't messed with anyone... I don't matter...why would they kill me?' But he did not understand that every day the situation would worsen. We did not leave until the very last minute."18

During the almost two years Pepi stayed with her sister, the teenager had a front row seat to the Algerian revolution: "Every day...maybe...first thing in the morning I remember I went to open the window and [she makes a gesture of terror] and heard FERME LA PORTE!! And I did so...OH MY GOD!! OH MY GOD!! Then, the entire street was...you know, because it was not very wide, the street was not very wide, the Rue Fondu(?)...it was not very wide... and when I went to open the window I discovered that the street was full of military or the gendarmerie...then everyone shouting, 'CLOSE THE WINDOW !!' and 'PURA!!' and she told me, 'CLOSE IT AND COME AWAY FROM THERE!' And it turns out that they were occupying the premises. They were searching all the floors... and searching people as well."

According to Spanish historian Roca, in a letter addressed to the High Commissioner of France, the Consul of Spain in Oran protested strongly against the police searches carried out in the homes of several Spaniards, presumably suspected of being members or sympathizers of the OAS. Almost sixty years later, Pepi ${ }^{19}$ recalled these searches with acute anxiety:

"Then my sister, so they would not take anything away from us, she had already made...because we already knew that this happened from time to time in other places and we had been warned...she sewed something like a purse...a pouch, she told me...one for her and one for me. But mostly for me because she could be searched more easily than me, since I was a young girl. Then, in that [the pouch] she put money, because we could not have it in a bank or anything...all the money that she had and the jewels. In one side and in another side. But of course, I put it underneath [my clothes] because they did not search you if you were a child. For me, the baby girls were my only refuge, I always protected them....always had them with me... and of course my sister Pura...yes. But no, they came in and asked us where we were from...they started telling us this and that...asking who we were 
and...but Juan was downstairs [at the bakery] because he could not get out either. ...He downstairs and... and us upstairs. Then they entered and searched the house and saw that there was nothing...they were looking for.... Yes...looking for weapons...weapons because below lived...the girl who was my French tutor and she had a boyfriend, a French pied-noir.... Then this young man was in that [referring to OAS]. And in our VERY FRONT DOOR [lengthens the syllables] I saw it...they killed him. I saw it. They killed him. So handsome he was. They killed him. And I saw it. And I saw everything, maybe I would look out on the balcony, because, you see, there was a family who lived across the street, a family that was...I do not remember right now...Madame Martínez...and many times she called out, 'INSIDE !!' They said, 'Pequeña, inside!' And I....and I said, 'Why?' 'Inside! Because I have three children and all three are in the revolution.' Of course, when something was about to happen, she would warn us, 'Inside' and if she said, 'Tell Madame Casquero to look out the window,' I would say, 'Pura, they are calling you' and Pura would tell me, 'Go inside with the girls' and... 'Inside, Madame Casquero.' 'All right,' and we would close down and go inside. Then, they [the gendarmes] would search the houses, and eventually they found a basement with weapons."

"And, of course, you can imagine the scare... one day I was on the street causally walking when a Moor came running from behind and killed a man right there. So, the first thing I would do was close the windows and run inside. While on the street the gendarmes, the local police, the military...with machine guns...the French pointing to all the balconies."

"I remember one day Carmen, my poor little angel...because, you see, my sister had two clothes lines on the balcony to hang out the laundry and there was a chair that Carmen would climb up on and she got tangled in between the two ropes. I noticed something out in the balcony, as I always paid close attention and saw her... and I said, 'CARMEN, CARMEN GET OFF!!' The girl was entangled and could not come down.... and I yelled, 'CARMEN FOR GOD'S SAKE'... and I picked her up swiftly and took her inside."

"The house was like this [she drew the rectangular shaped floor plan with her fingers on the table] the entrance of the street here and as you entered there was a long corridor, here was the bedroom, here was the dining room, and here was the kitchen. There were balconies in each room which overlooked the street...."

"To the left as you came into the house there was a closet. I slept in the dining room on a folding sofa bed. Of course, if the machine guns started to fire, the bullets crossed the windows... and entered here into the corridor. Then, the safest place to hide was here in the large closet, sitting on a chair with the two girls and that's where we hid.... Of course, I sat in the chair, took baby Marian in my arms and Carmen sitting on my other leg. I was so young, and they were so attached to me. I tightly embraced both of them... [she cried again] and thought, 'my god, 
what do I do if something happens to me? What if my sister does not come back?' [she paused to wipe her tears]."

Figure 30: Pepita and the girls, 1962

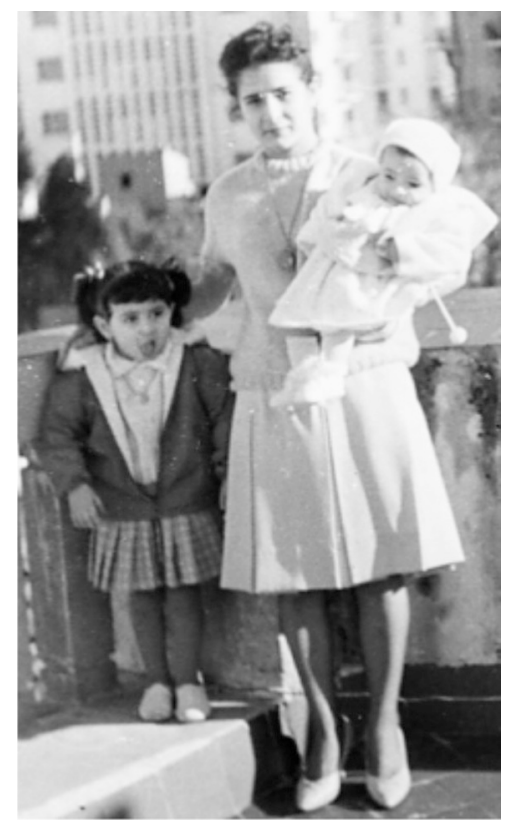

Algeria's independence was proclaimed on 5 July 1962. While the members in the OAS in France were mostly fascists, in Algeria they were politically diverse among the pied-noirs (French, Spanish, as well as Sephardic Jews). However, the FLN violent propaganda issued the slogan "The suitcase or the coffin" among the European colonists, provoking a mass exodus of people with their two allowable suitcases starting in April 1962. Between the $5^{\text {th }}$ and $7^{\text {th }}$ of July, the notorious "Oran massacre" took place. This massacre was an internal mass killing of Europeans living in the city. The death toll report varies from low estimates of 95 up to 453 casualties and missing. According to William Kidd, there were "3,000 European victims of FLN kidnappings and murders in the final months of the conflict whose remains have never been found." ${ }^{20}$ As the conflict escalated, the Casquero family started to make plans to leave. First, they had to evacuate Pepi. To do so, the consulate told

20 William Kidd, "(Un)packing the Suitcases: Postcolonial Memory and Iconography," in France's Colonial Legacies: Memory, Identity and Narrativeed. Fiona Barclay (Cardiff: University of Wales Press, 2013), 129-49 and 131-32. 
Juan they needed a letter from Pepi's father in Spain reclaiming her. Once the letter arrived, they had to go to the consulate in person to sign the paperwork. It was already late May 1962, close to the end of the war and very risky for Europeans to be walking on the streets. Pepi recounted the terrifying experience of going to the Spanish consulate located in the middle of the Arab quarter:

"Back then the consulate was in the Moors' neighborhood. We had to go from Oran [she was referring to the urban downtown] to the Moors' neighborhood. I had to go with Juan. He told me, 'Pepi, take my hand... and hold on to my jacket. DO NOT LET GO!!! But...if they catch me...GO AWAY!! RUN!! HIDE'... and I was only fourteen years old...the Moors...were all around us...like in the movies that you see.... That's why I don't like to watch those because people say, 'you are traumatized.' No, I'm not traumatized...but, ...yes, I still remember the fear. [she choked back tears] there are things that I can't stand even today...when you find yourself surrounded by a crowd and you are caught in the middle...."

"Well, we got through all that successfully. We arrived at the consulate. When they opened the door they were alarmed. 'Monsieur Casquero, por Dios!' and Juan said, 'I had no choice but to bring her because she has to sign.'.... They took us inside, gave us some water. I do not remember exactly. They sat me on a bench...they gave me water [and told me to] 'calm down' and I said 'yes, yes, I'm calm.' Meanwhile, my brother-in-law was in an office with the paperwork....whatever happened inside... all I know is that he cried, he cried...inside I don't know what happened but when he came out, he came out with red eyes from having cried.... He said, 'come on, we can go.' They took us back home in a car."

"When we arrived at the house Pura was beside herself with worry and began to cry. 'I thought you weren't coming back, not coming back, not coming back,' and the babies started to cry, especially Carmen in her toddler language, saying 'Don't go, don't leave me, DON'T LEAVE DON'T LEAVE ME.' Naturally, I spent all day taking care of them...they were so little.... The next step was complicated as well...because they told us that Franco was going to send a boat to repatriate the Spaniards, but only children and women, because...because....all the Spaniards, or almost all of them...or many of the Spaniards there were refugees from the war in Spain [the civil war.] So they COULDN'T return! Those poor people... but there were also people who didn't escape from the war...like Juan who had been a child, who had not run away from war but poverty. He could have returned, come back...everything. Pura could have evacuated with the girls...but she refused. She felt staying with her husband was her obligation. And I suggested, 'Pura, I'll take the girls.' And she said, 'Pepi, how could I let you take the girls by yourself?' 'Pura, I'LL TAKE THE GIRLS!' [Supplicant intonation] [crying silently]."

For Pepi, the return to Spain was as traumatic as the preparations. She traveled by boat from Oran to Alicante by herself with the two allotted suitcases on a ship packed with desperate people. A family temporarily adopted her so she would not 
be harassed by the sailors. After a terrifying night and half a day more, the ship arrived in Alicante, where a family friend was waiting for her. She spent one night and then the next day boarded a train to Granada. She remembers how a man sat next to her on the train and kept asking questions, offering her something to eat. The man proved to be useful as he scolded some young soldiers who later boarded the train and started harassing her. The man turned out to be a police officer who made sure upon arrival in Granada that the people waiting on the platform were indeed Pepi's family.

My Aunt Pura did not mention any of this ordeal when I interviewed her in 2002. What she didn't relate to me then, now takes on a larger significance. In historical narratives what is not included is often just as important as what is. Imagining different perspectives or, as in this account, looking for them, is essential to filling in that space.

My cousins tell me their family sent some of the furniture, and their father salvaged many documents, contracts, bills of purchase, and the blueprints for a bungalow they planned to build by the seaside on a plot of land they had bought-everything that could fit in his two suitcases. But they lost everything. No recourse. They were foreigners in a foreign land, with no rights, and despised by the French in Toulon, where they stayed until their father retired: "I remember my mother saying that they had to close the store door and flee...everything lost. They had bought a piece of land on the beach that they also lost. And they had to leave by boat to Alicante. And with very little.... I do remember how my mother told us she hid money in the head of one of the dolls my sister and I carried in our arms."

"My father...went first to Paris because my Uncle Jeanot was there. But he didn't like it...a very big city...he liked more coastal and warmer places. Of course, Oran is on the coast too...it's on the same Mediterranean coast. And then also, all the French who lived in Algeria, the vast majority arrived in the area of the French Riviera. The pied-noirs settled in Marseille, Toulon, Nice, Cannes...that whole area is where they went, most of them because of the weather, the sea, because of the environment they went there. And there we stayed in Toulon."

An important contingent of French pied-noirs connected or sympathetic to the OAS established themselves in Alicante, Spain. According to Juan David Sempere, during the first three years following independence, a few dozen OAS activists resided in Alicante and even "commands were prepared with the mission of attacking De Gaulle." All this was possible in the midst of the Francoist dictatorship. ${ }^{21}$ The

21 "It is difficult to know how many people passed or settled in the city and in the province due to the absence of specific counts and the internal diversity of the collective: Spaniards who simply returned to their villages and neighborhoods of origin; French who did not want or did not think about going through the French consulate reopened at that time, people who no longer had contacts in the place of origin of their ancestors. There are figures that usually 
city of Alicante, which had been a small provincial capital, became a cosmopolitan enclave with the arrival of the newcomers. The pied-noirs even established a French school and a newspaper called Le courrier du soleil and brought important economic and social changes to the region. However, Juan decided to relocate in France rather than stay in Francoist Spain.

In evaluating their mother's decisions, my cousins are clearly impressed by her fortitude. Carmen admires how Pura overcame adversity and was able to start anew again and again:

"To begin with, my mother was brave to go to an unknown country and without knowing the language...that was her first life...a first stage...then she had to change again to a different country, even if it was still the French language, and started over again... Because my father had to start over. He stopped being an entrepreneur and became a simple worker in a bakery.... And then when my father retired, they came here to Granada and it was again having to start from zero here too. And she was always a rock.... If it hadn't been for her and her sheer determination... [her voice trailed off] Because my father was more...do you remember? Quieter...very quiet."

"My mother was the one in charge and the one who made decisions and the one who moved forward...braver in that respect, no? ...To remake our lives three times. Also, when they returned to Spain, they only had a small retirement pension, as they were not able to be compensated for the many years they had contributed in France and especially Algeria.... The latter was lost. We had to look... my father had to work again after retirement for a while in the bakery Olimpia, on the Gran Vía [in Granada]...until they were able to open a little place on Avenida de Pulianas."

range between twenty and forty thousand people, and especially of the 30,000 pieds-noirs mentioned in the magazine they created, Le courrier du soleil, and with which Antoni Seva Llinares titled his book in 1968. But in the absence of sources of information and knowing if they refer to the city or the province, it is not possible to confirm this figure. Reliable counts are well below the indicated figures. In 1970 the French consul in Alicante had six thousand French registered, most of them from Algeria, although he estimated between ten and fifteen thousand the number of French people living in the province. On the other hand, in the 1965 census of the municipality of Alicante only 2,778 people originating in Algeria had been counted, but it allows us to confirm that they had a balanced structure by age and sex, that they were mostly merchants, employees, and workers, and that initially they were distributed throughout the city but especially in the neighborhoods of the Center, Carolinas, and El Pla." See Juan David Sempere Souvannavong, "Cincuenta años con los pies negros," Información July 26, 2012. https://www.diarioinformacion.com/arte-letras/2012/07/26/cincuenta-anospies-negros/1278748.html. Antoni Seva Llinares, Alacant, trenta mil pieds-noirs (Alicante: Eliseo Clement, 1968) was one of the original studies of the diáspora. See also: Juan David Sempere Souvannavong, Los 'Pieds Noirs' en Alicante: Las migraciones inducidas por la descolonización (Alicante: Publicaciones Universidad de Alicante, 1998). 
Figure 31: Juan Casquero with his

daughters, after he retired to Granada

in 1971

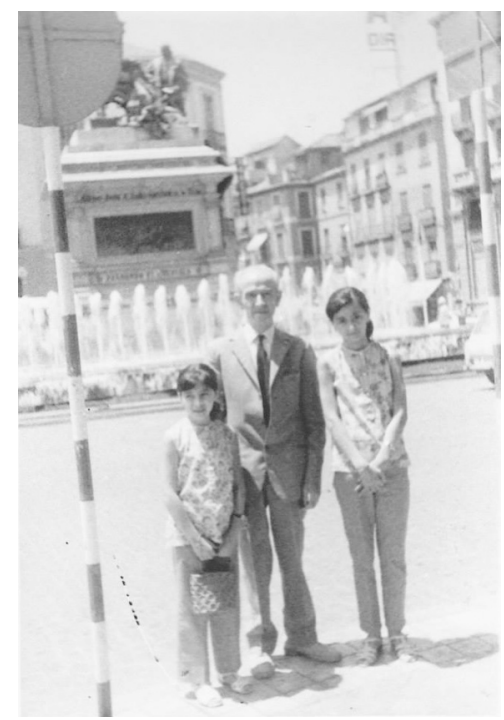

Marian also applauds her mother's choices, in particular marrying her father: "Well, that's why I say that when my mother met my father... and he told her, 'Look, I can't have children. Does that matter?' And my mother replied [Marian laughing], 'Me? Matter to me? I have raised eight already!!' [laughs heartily] She must have thought, 'You are the perfect husband! The perfect husband...look, you get me out of here. [she speaks with emotion] A new life! A new life in which I will not have to work even one day, a life without children? [she says with emphasis] Right now I'll sign whatever, whenever, where do I sign?' ...A month it took her to decide...A month!! You know what I mean, now?"

"And so the first baby arrives unexpectedly...because it was not in her plans and the second one....another?...yes, yes, yes, yes...Another...And I know that she got pregnant with another child who was a boy...because they...expected me to be a boy and so they would have the pair, boy and girl...but the stork brought a girl...me, the mistake [she laughs] And with the mess in the war and all that...."

Although Marian and her mother did not always get along, she has tender memories of the final years caring for her mother after Pura suffered the ultimate act of forgetting-Alzheimer's: "Although it was difficult...because I was not close with my mother...neither in my adolescence, nor when I married or anything.... Then I 
saw my mother as far away [short pause] would be for that...because we looked like each other...because we didn't get along.... Then comes the disease...she stopped eating...." Pura forgot how to swallow, and the doctors decided it was not worth it to try to retrain her, as swallowing is not an involuntary action. But Marian was adamant and took her in her arms like a baby, massaging the food down her throat, every day, until her last breath. 